\title{
Comparison Some Fruit Characteristics of Eggplant Population with Their Selfing Lines
}

\author{
Vedat Pirinc (Corresponding author) \\ Dicle University, Faculty of Agriculture, Department of Horticulture, \\ 21280 Diyarbakir, Turkey \\ E-mail:vedpir@dicle.edu.tr \\ Ayse Yildiz Pakyurek \\ Horticulture Department, Agriculture Faculty, Harran University, \\ Sanliurfa, Turkey \\ E-mail:aypak@harran.edu.tr
}

\begin{abstract}
The aim of this research was to compare the some fruit characteristics of eggplant population with their selfing lines. The selection programme was conducted to get promising breeding lines from eggplant population of Sanliurfa. The study included 6 population (Surtepe, Altinova, Magarali, Ugurlu, Mezra and Keskince) collected from different villages of Sanliurfa where mostly growing. In the first year, 20 lines were obtained from the populations by selection program using selfing method. The scale taken from UPOV, applied in both population and selfing lines to determine the characteristics of fruit. Fruit characteristics were compared between in each population with its selfing lines, such as ratio of fruit length/diameter, fruit curvature, shape of apex, level of glossiness on fruit skin, length of fruit stalk, size of calyx, spinyness of calyx, intensity of anthocyanin below calyx, length of flower stalk, purple level of flower. All features were evaluated according to statistical values so some of the lines had significant differences from its population. Mezra 1, Mezra 4 and Mezra 5 had significant difference from its population for ratio of fruit length/diameter; Surtepe 1, Altinova 4, Mezra 1, 4, 5 and Mezra 6, lines had significant differences from the population for shape of apex. In level of glossiness on fruit skin Altinova 2, 3 and Altinova 4 lines and Mezra 4, Keskince 3 and 5 lines had significant difference from the population in statistical means. Most of the characterization of lines can be certain parameters to develop new varieties. And also Rankit-Weighted Method was applied to the lines to choose the best line or lines for some important fruit characteristics preferred by local consumer. Surtepe 1, Surtepe 2, Mezra 5 and Keskince 3 breeding lines got 750 and over score, so it will be essential to carry on the research with these lines.
\end{abstract}

Key Words: Eggplant; Population; Breeding; Lines.

DOI: $10.7176 / \mathrm{JSTR} / 5-12-27$

\section{Introduction}

Eggplant (Solanum melongena L) is very important vegetable in all over the country and has great different meal in each ecology of Turkey. It is not only fresh consumption but also evaluated as processed product such as dried, pickling, canned food, roasted, jam and etc. and it has more than 20 meals in Turkish kitchen. Eggplant is poor for A and $\mathrm{C}$ vitamins but contains vitamins $\mathrm{B}\left(\mathrm{B}_{1} ; 0.04-0.09, \mathrm{~B}_{2} ; 0.02\right.$ 0.05 , Niacin; 0.060) in normal amounts (Şalk et. al., 2008). Eggplant is poor for oil contain so it can be eat without being fat so it is easily joined in diet menu. The primary origin of the eggplant is regarded as India and it was first cultivated there as the primary centre of origin and diversity (Kumar et al., 2013). The eggplant arrived in Europe around 1300, and the fruits were used as food after the sixteenth century (D'Anna and Sabatino 2013). The introduction of the eggplant to the west was primarily around the Mediterranean region, which is the secondary "domestication region" and covers Turkey, Syria and Persia (Küçük 2003; Daunay et al., 2001; Tümbilen 2007). Many local eggplant landraces are found in Turkey. These landraces are grown by producers in almost all regions (Balkaya and Karaagac 2005). 
These traditional landraces are an important genetic resource for plant breeders because of their considerable genotypic variation. Turkey has different ecologic conditions and each region has diversity of eggplant varieties; mediternean region has round eggplant but South-east Region has cylindrical shape of eggplant. Tümbilen et al., 2011; reported an article about eggplant populations, in this study, the genetic variability of 67 Turkish eggplant accessions from the national germplasm collection was assessed with 30 morphological traits and AFLP markers. Morphological analysis indicated considerable variability especially for semi-long and round types. South-East region consume eggplant especially Sanliurfa with a great amount. In these region local eggplant preferred for all meals and it has an important place in vegetable production. And vegetable productions will be increased by new irrigation area with South-east Anatolian Project.

South-East Anatolian Project (GAP) takes great interest in Turkey and also in world, due to irrigated areas and electric production. By increasing irrigated areas the climate of the region will be changed, and new agricultural areas allow to grow new species in this region so the vegetables growing will be increased as others. Sanliurfa has a great role in GAP area and vegetables are consumed especially the local varieties such as eggplant and it is very important in daily and diet meals. It is estimated that area of vegetable growing will take a 5-8 \% part of the irrigated fields in the region according to Projection of GAP (Abak et. all., 1996). Turkey has 836.284 ton eggplant production and Sanliurfa has 23.282 ton eggplant production (Anonymous, 2018). This region consumed cylindrical eggplant in all meals. Instead of having population characteristic, the eggplant populations achieved to come todays because of delicious taste preferred by people and resistance to stress factors in this ecology. However it seem new varieties will joined to the region with irrigation this may caused to lose the local genetic material. Local breeding material has lot of best features especially the fruit characteristics such as color of fruit and flesh, but these had changed in the time having population characteristics (Pirinç and Pakyürek, 2001). Eggplant populations have different fruit characteristics, some of them is suitable for local meal such as kebap (long, thin and black color of fruit is used) and watery meal (a little fat, dark purple whitish flesh fruits) and also different plant features such as plant attitude; erect and semi erect, etc., (Pirinç, 1999). The eggplant populations are also very popular in all over the country. One of the study on the population has began in 1997 by Master Thesis (Pirinç, 1999) and the comparison of some most important characteristics (fruit length, color of skin at commercial harvesting and color of flesh, plant length and also the yield, etc.) are obtained in Şanliurfa eggplant population and issued in recent article (Pirinç and Pakyürek, 2001; Pirinç and Pakyürek 2004).

The main purpose of this research is to get homozygote, diploid new variety or varieties by selection program using selfing method increasing the purification of eggplant selfing lines. The selection program is also included Weighted-Rankit Method to choose the best lines on some of the best fruit characteristics among lines by take attention the consumers' demands and to prevent the duplicate some of the fruit characteristics gave in recent article is notified with degree gotten from Weighted-Rankit method. By this research some of fruit characteristics were obtained in Şanliurfa eggplant population to compare them with their selfing lines. The best lines will be include into breeding programme for developing new variety.

\section{Material and Methods}

This study was conducted during the vegetative seasons of 1997 and 1998 years at the research area of Horticulture Department of Agriculture Faculty, University of Harran. The seeds used in the experiment were collected from Surtepe, Mezra, Altinova, Ugurlu, Keskince and Magaralı village of Sanliurfa. The names given to the population are the names of the village where they were grown. The seeds were sown on April 11, 1997 and March 28, 1998 in seedling viols. The seedlings were transplanted in the experimental area on June 1, 1997 and May 22, 1998. The experiment was set up with 20 plants per plot, having $100 \mathrm{~cm}$ between rows and $50 \mathrm{~cm}$ within row spacing. In the first year harvest for commercial began on 28. June and continued till 15 Oct. for all population and lines. The fruits were harvested during Sept.- Oct. each year, when they appeared to attain physiological ripeness for seed production. The lines were selected from each populations in the first year of the study. The populations and selected number of lines were given in Table 1. The selfing was done to prevent foreign pollination. The selfing was done 06:30 - 09:30 a.m and 05:30 - 07:30 p.m. The scales developed by UPOV (International Union for the Protection of New Varieties Plants) were used for varieties of Solanum melongena L.) (Anonymous, 1988). The measurements and observations were recorded on some characteristics of eggplant population and their lines such as; length of fruit stalk $(\mathrm{cm})$, fruit curvature, shape of apex, level of glossiness on fruit skin, length of fruit stalk $(\mathrm{cm})$, size of calyx, spinyness of calyx, intensity of anthocyanin below calyx, intensity of anthocyanin below calyx, length of flower stalk $(\mathrm{cm})$, purple level of flower. These characteristics are given in this issue and also other characteristics were given in recent paper (Pirinç et. 
all., 2001) such as; plant attitude, plant height $(\mathrm{cm})$, length of internode $(\mathrm{cm})$, length of leaf $(\mathrm{cm})$, fruit length $(\mathrm{cm})$, fruit diameter $(\mathrm{cm})$, color of skin commercial harvest and color of flesh.

The all measurements were recorded at the $3^{\text {rd }}$ harvest period. Weighted-Rankit Method was applied to all lines only for some important properties. The Variance analyses were applied to the results with Tarist Statistical Software Program (Açıkgöz et all., 1994). T-Test was used to analyze the differences among means. The data obtained from each line were compared to its local population in order to determine the differences.

Table1. Population and selected number of lines.

\begin{tabular}{|c|c|c|c|c|c|c|}
\hline Population & Surtepe & Altinova & Magarali & Uğurlu & Mezra & Keskince \\
\hline Number of lines & 3 & 4 & 2 & 1 & 6 & 5 \\
\hline
\end{tabular}

\section{Results and Discussion}

The ratio of fruit length/diameter, fruit curvature, shape of apex, and level of glossiness on fruit skin were shown in Table 1. Mezra 1, Mezra 4 and Mezra 5 lines have significant statistical differences for ratio of length/diameter. The differences within the population was insignificant. Mezra 5 line has significant differences in view of fruit curvature, and this line was more curvature than its population. Shape of apex was changed in lines; Surtepe 1 Altinova 4, Mezra 1, Mezra 4, Mezra 5 and Mezra 6 for shape of apex had differences. While Mezra 1, 4, 5, 6 have rounded apex, the population of Mezra has intended apex shape. Altinova 2, 3, 4, Mezra 4, Keskince 3 and Keskince 5 lines had significant differences statistically for level of glossiness on fruit skin. From these lines only Keskince 3, 4 and Keskince 5 lines had medium glossiness level others have strong.

The data on length of fruit stalk, size of calyx and spinyness of calyx were given in Table 3 . There were no significant differences between lines and population except Altinova and Keskince for fruit stalk. Altinova 2, 3 and 4 lines were more different than the population. Because long stalk is not recommended, these lines are favour for this character but Keskince 1, 4 and 5 lines have shorter fruit stalk than the populatin and this shorting is important because consumer like shorter fruit stalk and it is practical for handling Size of calyx is an important character for eggplant, and in fact large calyx is not preferred. For this character only Altonova 3 line was significantly different from its population; because this line had medium calyx otherwise its population. Spinyness of calyx is a genetical character but also affected with environment condition that is not recommended. Most of varieties had spiny calyx. The lines; Surtepe 1, Surtepe 2, Altinova 2, Altinova 3, Altinova 4, Mezra 2, Mezra 4, Mezra 6, and Keskince 3 have significantly different from populations (Figure 1).

The data about intensity of anthocyanin below calyx, length of flower stalk, purple level of flower were given in table 4. As shown in table 4; Surtepe 1, Surtepe 2, Altinova 1, Altinova 4, Ugurlu 1, Mezra 1, Mezra 2, Mezra 3, Mezra 4, Keskince 2 ve Keskince 4 lines have non-significant according to $\mathrm{T}$ value while statistically comparing wtih their population but, Altinova 2, Altinova 3, Magarali 1, Magarali 2, Mezra 5, Mezra 6, Keskince 1, Keskince 3 ve Keskince 5 lines different from their population so these lines have statistical significant differences from the population, Intensity of anthocyanin below calyx is common and genetical characteristics in purple eggplant. When the $\mathrm{T}$ value was taken into consideration as a result of comparison with the populations of the lines in terms of length of flower stalk only Altinova 3, Altinova 4 and Magarali 2 lines showed differences and the difference was statistically significant. The difference between the other lines and their populations was nonsignificant. When the table 4. is examined; Surtepe 2, Altinova 1, Altinova 4, Magarali 1, Magarali 2, Ugurlu 1, Mezra 1, Mezra 3, Mezra 4, Mezra 5, Mezra 6, Keskince 2, Keskince 3, Keskince 4 and Keskince 5 lines compared with the population of the $\mathrm{T}$ value the difference between them is insignificant for purple level of flower, but Surtepe 1, Altinova 2, Altinova 3, Mezra 2 and Keskince 1 as a result of the comparison between the populations of the difference is statistically significant. One of the latest study was conducted in Samsun region and the results provided information on the diversity, and this identified eggplant genetic resources to be evaluated for the development of new candidate varieties in future breeding activities (Çakır, et all., 2017). They used seventy five populations of eggplant for characteziation using standard morphological descriptors. 
Table 2. Averages values of ratio of fruit length/diameter, fruit curvature, Shape of apex, Level of glossiness on fruit skin

\begin{tabular}{|c|c|c|c|c|}
\hline $\begin{array}{c}\text { Population } \\
\text { and } \\
\text { Lines }\end{array}$ & $\begin{array}{c}\text { Ratio of fruit } \\
\text { length/ } \\
\text { Diameter }\end{array}$ & $\begin{array}{c}\text { Fruit } \\
\text { Curvature }\end{array}$ & $\begin{array}{l}\text { Shape } \\
\text { of apex }\end{array}$ & $\begin{array}{c}\text { Level of } \\
\text { glossiness on } \\
\text { fruit skin }\end{array}$ \\
\hline Surtepe & $4.89( \pm 1.0)$ & $2.5( \pm 0.7)$ & $1.60( \pm 0.5)^{*}$ & $1.2( \pm 0.4)$ \\
\hline Surtepe 1 & $4.95( \pm 0.6)$ & $2.5( \pm 0.5)$ & $2.0( \pm 0.0)$ & $1.2( \pm 0.4)$ \\
\hline Surtepe 2 & $4.62( \pm 0.7)$ & $2.5050( \pm 0.5)$ & $1.8( \pm 0.4)$ & $1.1( \pm 0.3)$ \\
\hline Altinova & $4.36( \pm 0.3)$ & $2.4( \pm 0.8)$ & $1.8( \pm 0.4)$ & $2.6( \pm 0.7)$ \\
\hline Altinova 1 & $4.83( \pm 0.8)$ & $2.2( \pm 0.4)$ & $1.9( \pm 0.3)$ & $2.2( \pm 0.4)$ \\
\hline Altinova 2 & $3.95( \pm 0.8)$ & $2.1( \pm 0.3)$ & $1.6( \pm 0.5))$ & $1.2( \pm 0.4)^{* *}$ \\
\hline Altinova 3 & $3.80( \pm 0.6)$ & $2.5( \pm 0.5)$ & $2.3( \pm 0.5)$ & $1.2( \pm 0.4)^{* *}$ \\
\hline Altinova 4 & $4.32( \pm 0.8)$ & $2.0( \pm 0.7)$ & $2.9( \pm 0.3) * *$ & $1.4( \pm .5)^{* *}$ \\
\hline Magaralı & $4.58( \pm 0.2)$ & $2.2( \pm 0.4)$ & $1.8( \pm 0.4)$ & $1.8( \pm 0.6)$ \\
\hline Magaralı 1 & $4.37( \pm 0.6)$ & $2.4( \pm 0.5)$ & $2.0( \pm 0.0)$ & $2.2( \pm 0.6)$ \\
\hline Magaralı 2 & $4.45( \pm 0.5)$ & $2.5( \pm 0.7)$ & $2.2( \pm 06)$ & $1.8( \pm 0.6)$ \\
\hline Ugurlu & $4.18( \pm 0.8)$ & $2.1( \pm 0.3)$ & $1.7( \pm 0.5))$ & $1.8( \pm 0.4)$ \\
\hline Ugurlu 1 & $4.21( \pm 0.5)$ & $2.0( \pm 1.1)$ & $1.9( \pm 0.3)$ & $2.4( \pm 0.5)$ \\
\hline Mezra & $3.69( \pm 0.3)$ & $2.3( \pm 0.5)$ & $1.3( \pm 0.5)$ & $2.2( \pm 0.4)$ \\
\hline Mezra 1 & $4.70( \pm 0.5)^{* *}$ & $2.1( \pm 0.3)$ & $1.9( \pm 0.3)^{* *}$ & $2.3( \pm 0.8)$ \\
\hline Mezra 2 & $3.90( \pm 0.8)$ & $2.1( \pm 0.3)$ & $1.2( \pm 0.4)$ & $1.7( \pm 0.5)$ \\
\hline Mezra 3 & $3.77( \pm 0.7)$ & $2.1( \pm 0.7)$ & $1.4( \pm 0.5)$ & $2.0( \pm 0.0)$ \\
\hline Mezra 4 & $4.20( \pm 0.5)^{* *}$ & $2.7( \pm 0.7)$ & $2.1( \pm 0.7)^{* *}$ & $1.3( \pm 0.5) * *$ \\
\hline Mezra 5 & $4.75( \pm 0.5) * *$ & $3.0( \pm 0.5) * *$ & $1.8( \pm 0.4)^{* *}$ & $2.4( \pm 0.5)$ \\
\hline Mezra 6 & $4.22( \pm 0.6)$ & $2.4( \pm 0.8)$ & $1.8( \pm 0.4)^{* *}$ & $2.1( \pm 0.3)$ \\
\hline Keskınce & $4.17( \pm 0.5)$ & $2.3( \pm 0.5)$ & $2.1( \pm 0.3)$ & $1.3( \pm 0.5)$ \\
\hline Keskince 1 & $4.23( \pm 0.6)$ & $2.2( \pm 0.6)$ & $1.9( \pm 0.6)$ & $1.8( \pm 0.4)$ \\
\hline Keskince 2 & $4.46( \pm 0.7)$ & $2.4( \pm 0.7)$ & $2.2( \pm 0.4))$ & $1.4( \pm 0.5)$ \\
\hline Keskince 3 & $4.33( \pm 0.4)$ & $1.9( \pm 1.2)$ & $2.1( \pm 0.3)$ & $2.3( \pm 0.5) * *$ \\
\hline Keskince 4 & $4.22( \pm 0.6)$ & $2.2( \pm 0.8)$ & $2.2( \pm 0.6)$ & $1.6( \pm 0.5)$ \\
\hline Keskince 5 & $3.59( \pm 0.5)$ & $2.1( \pm 0.6)$ & $1.8( \pm 0.6)$ & $2.3( \pm 0.5) * *$ \\
\hline
\end{tabular}


Table 3. Average value of length of fruit stalk, size of calyx, Spinyness of calyx

\begin{tabular}{|c|c|c|c|}
\hline $\begin{array}{l}\text { Population } \\
\text { and } \\
\text { Lines }\end{array}$ & $\begin{array}{l}\text { Length of } \\
\text { fruit stalk } \\
\text { (cm) }\end{array}$ & $\begin{array}{c}\text { Size } \\
\text { of } \\
\text { calyx }\end{array}$ & $\begin{array}{c}\text { Spinyness } \\
\text { of } \\
\text { calyx }\end{array}$ \\
\hline Surtepe & $7.59( \pm 1.1)$ & $1.1( \pm 0.3)$ & $1.4( \pm 0.8)$ \\
\hline Surtepe 1 & $6.35( \pm 1.5)$ & $1.2( \pm 0.4)$ & $2.8( \pm 0.4)^{* *}$ \\
\hline Surtepe 2 & $6.25( \pm 1.5)$ & $1.0( \pm 0.0)$ & $3.0( \pm 0.0)^{* *}$ \\
\hline Altinova & $7.72( \pm 1.2)$ & $1.1( \pm 0.3)$ & $2.0( \pm 0.5)$ \\
\hline Altinova 1 & $6.82( \pm 1.0)$ & $1.1( \pm 0.3)$ & $2.0( \pm 0.9)$ \\
\hline Altinova 2 & $6.23( \pm 0.8)^{* * *}$ & $1.4( \pm 0.5)$ & $2.7( \pm 0.5) * *$ \\
\hline Altinova 3 & $9.00( \pm 1.3)^{* *}$ & $1.9( \pm 0.6)^{* *}$ & $3.0( \pm 0.0)^{* *}$ \\
\hline Altinova 4 & $6.21( \pm 1.0)^{* *}$ & $1.3( \pm 0.5)$ & $1.4( \pm 0.5) * *$ \\
\hline Magaralı & $7.21( \pm 1.1)$ & $1.1( \pm 0.3)$ & $2.4( \pm 0.5)$ \\
\hline Magaralı 1 & $6.44( \pm 0.8)$ & $1.3( \pm 0.7)$ & $2.6( \pm 0.5)$ \\
\hline Magaralı 2 & $6.44( \pm 0.8)$ & $1.3( \pm 0.7)$ & $2.4( \pm 0.7)$ \\
\hline Ugurlu & $7.80( \pm 1.3)$ & $1.7( \pm 0.5)$ & $2.6( \pm 0.5)$ \\
\hline Ugurlu 1 & $6.75( \pm 1.0)$ & $1.3( \pm 0.5)$ & $2.5( \pm 0.5)$ \\
\hline Mezra & $7.74( \pm 0.8)$ & $1.6( \pm 0.5)$ & $1.9( \pm 0.3)$ \\
\hline Mezra 1 & $7.45( \pm 0.9)$ & $1.3( \pm 0.5)$ & $2.2( \pm 0.4)$ \\
\hline Mezra 2 & $7.37( \pm 1.0)$ & $2.1( \pm 0.7)$ & $1.0( \pm 0.0)^{* *}$ \\
\hline Mezra 3 & $7.42( \pm 1.1)$ & $1.3( \pm 0.5)$ & $1.6( \pm 0.7)$ \\
\hline Mezra 4 & $6.80( \pm 1.0)$ & $1.6( \pm 0.7)$ & $2.5( \pm 0.5) * *$ \\
\hline Mezra 5 & $7.79( \pm 0.9)$ & $1.2( \pm 0.4)$ & $1.6( \pm 0.7)$ \\
\hline Mezra 6 & $6.74( \pm 1.4)$ & $1.2( \pm 0.4)$ & $2.6( \pm 0.5)^{* *}$ \\
\hline Keskınce & $7.62( \pm 0.8)$ & $1.1( \pm 0.3)$ & $2.0( \pm 0.0)$ \\
\hline Keskince 1 & $6.72( \pm 0.7)^{* *}$ & $1.1( \pm 0.3)$ & $3.0( \pm 0.0)$ \\
\hline Keskince 2 & $6.82( \pm 1.3)$ & $1.4( \pm 0.5)$ & $2.7( \pm 0.5)$ \\
\hline Keskince 3 & $7.34( \pm 1.0)$ & $1.1( \pm 0.3)$ & $1.4( \pm 0.5) * *$ \\
\hline Keskince 4 & $6.71( \pm 0.7)^{* *}$ & $1.1( \pm 0.3)$ & $2.3( \pm 0.5)$ \\
\hline Keskince 5 & $5.74( \pm 1.2)^{* *}$ & $1.5( \pm 0.7)$ & $2.2( \pm 0.8)$ \\
\hline
\end{tabular}


Table 4. Average value of Intensity of anthocyanin below calyx, Length of flower stalk, Purple level of flower

\begin{tabular}{|c|c|c|c|}
\hline $\begin{array}{c}\text { Population } \\
\text { and } \\
\text { Lines } \\
\end{array}$ & $\begin{array}{l}\text { Intensity of } \\
\text { anthocyanin } \\
\text { below calyx }\end{array}$ & \begin{tabular}{|lr}
$\begin{array}{l}\text { Length } \\
\text { flower } \\
(\mathbf{c m})\end{array}$ \\
\end{tabular} & $\begin{array}{l}\text { Purple level } \\
\text { of } \\
\text { flower } \\
\end{array}$ \\
\hline Surtepe & $3.9( \pm 0.3)$ & $2.9( \pm 0.5)$ & $1.4( \pm 0.5)$ \\
\hline Surtepe 1 & $4.0( \pm 0.0)$ & $2.6( \pm 0.4)$ & $1.8( \pm 0.4)^{* *}$ \\
\hline Surtepe 2 & $3.9( \pm 0.3)$ & $3.0( \pm 0.7)$ & $1.7( \pm 0.7)$ \\
\hline Altinova & $1.8( \pm 0.6)$ & $2.9( \pm 0.5)$ & $1.6 \pm 0.7)$ \\
\hline Altinova 1 & $2.1( \pm 0.9)$ & $2.5( \pm 0.4)$ & $1.8( \pm 0.4)$ \\
\hline Altinova 2 & $2.7( \pm 0.8)^{* *}$ & $3.2( \pm 0.4)$ & $2.3( \pm 0.5)^{* *}$ \\
\hline Altinova 3 & $1.0( \pm 0.0)^{* *}$ & $3.5( \pm 0.5)^{* *}$ & $2.7( \pm 0.5)^{* *}$ \\
\hline Altinova 4 & $1.6( \pm 0.5)$ & $3.6( \pm 0.6) * *$ & $2.2( \pm 0.4)$ \\
\hline Magaralı & $1.7( \pm 1.2)$ & $2.7( \pm 0.6)$ & $1.8( \pm 0.6)$ \\
\hline Magaralı 1 & $3.5( \pm 0.7) * *$ & $2.5( \pm 0.3)$ & $1.9( \pm 0.6)$ \\
\hline Magaralı 2 & $2.7( \pm 1.1)^{* *}$ & $3.3( \pm 0.4) * *$ & $2.2( \pm 0.4)$ \\
\hline Ugurlu & $2.7( \pm 0.5)$ & $2.8( \pm 0.6)$ & $1.9( \pm 0.6)$ \\
\hline Ugurlu 1 & $1.9( \pm 1.2)$ & $2.9( \pm 0.5)$ & $1.8( \pm 0.6)$ \\
\hline Mezra & $1.3( \pm 0.5)$ & $2.9( \pm 0.4)$ & $1.8( \pm 0.6)$ \\
\hline Mezra 1 & $2.0( \pm 0.8)$ & $2.8( \pm 0.6)$ & $1.8( \pm 0.6)$ \\
\hline Mezra 2 & $1.1( \pm 0.3)$ & $2.8( \pm 0.4)$ & $2.7( \pm 0.5)^{* *}$ \\
\hline Mezra 3 & $1.4( \pm 0.5)$ & $2.7( \pm 0.5)$ & $1.8( \pm 0.4)$ \\
\hline Mezra 4 & $2.1( \pm 1.0)$ & $3.2( \pm 0.3)$ & $1.9( \pm 0.5)$ \\
\hline Mezra 5 & $2.1( \pm 0.7)^{* *}$ & $2.6( \pm 0.4)$ & $1.9( \pm 0.6)$ \\
\hline Mezra 6 & $3.2( \pm 0.7)^{* *}$ & $2.7( \pm 0.4)$ & $1.9( \pm 0.3)$ \\
\hline Keskince & $1.3( \pm 0.7)$ & $3.1( \pm 0.7)$ & $2.3( \pm 0.5)$ \\
\hline Keskince 1 & $2.3( \pm 0.5)^{* *}$ & $2.8( \pm 0.3)$ & $1.4( \pm 0.5)^{* *}$ \\
\hline Keskince 2 & $1.6( \pm 0.7)$ & $3.1( \pm 0.6)$ & $2.2( \pm 0.4)$ \\
\hline Keskince 3 & $1.7( \pm 0.8)^{* *}$ & $2.6( \pm 0.6)$ & $1.8( \pm 0.4)$ \\
\hline Keskince 4 & $1.0( \pm 0.0)$ & $3.0( \pm 0.5)$ & $2.3( \pm 0.7)$ \\
\hline Keskince 5 & $1.8( \pm 0.8) * *$ & $3.1( \pm 0.7)$ & $1.9( \pm 0.3)$ \\
\hline
\end{tabular}

(**significant at $\% 5$ Alfa, *: significant at $\% 1$ Alfa, n: 10 (number of example)) Scales for Intensity of anthocyanin below calyx: absent: 1; weak: 2; medium:3; strong: 4 Scales for colour of flower of purple level: Dark purple: 1 , middle purple: 2 , light purple: 3 


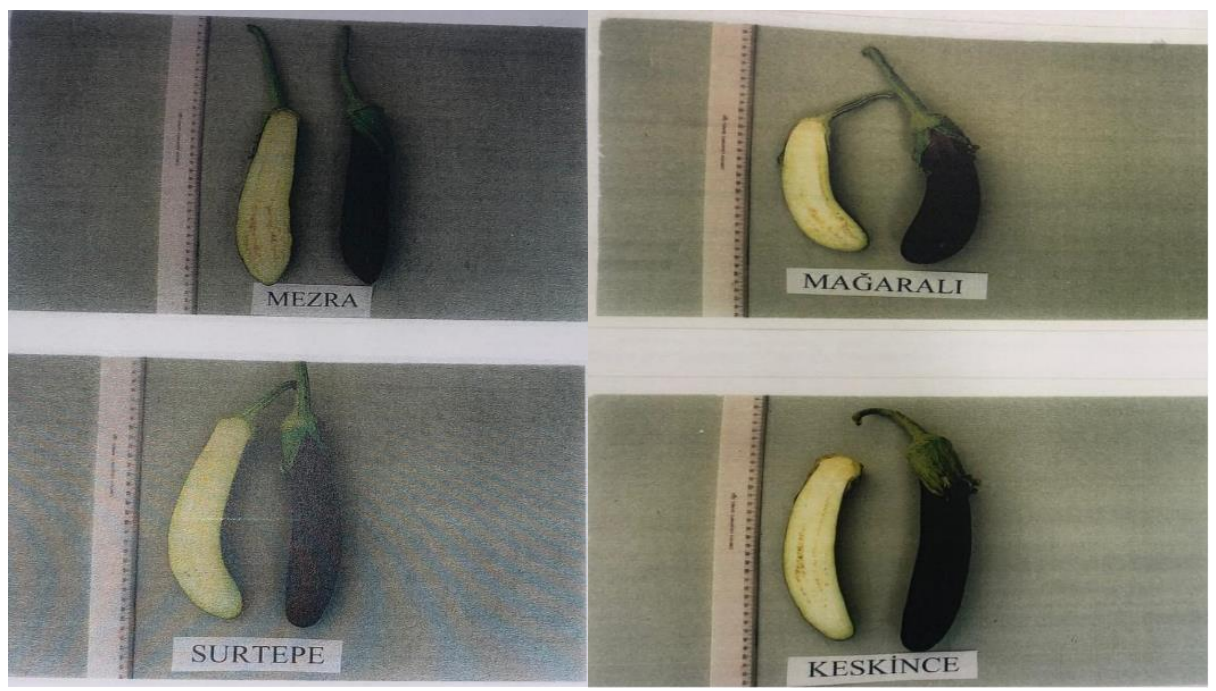

Figure 1. Fruits of Eggplant populations.

\section{Conclusion}

In the light of the data obtained, in order to help other studies to be carried out in the future, superior lines were selected by applying the Rankit-Weighted Method in some quality criterias in the eggplant in Table 5. The scoreboard of lines were given according to Rankit-Weighted Method. In addition, maximum and minimum values obtained from the measurements were taken into consideration in the evaluation. In Table 6, the rating scores of all lines according to the characteristics examined were given. At the end of the assessment, the lines those have 760 and above degree were selected, similar study has the same results for lines of Seyhkent population (Pirinç and Pakyürek, 2004). And these are canditates variety for selection programme. A recent study was conducted on local eggplant populations and their lines (Sarıbaş, et all., 2019) used Rankit-Weighted Method; the evaluations were made according to the weighted ranking method. It was determined that the eggplant genotypes have a total score between 290 and 475 point. According to the selection scores, a total of 20 eggplant genotypes with a score of 420 point and above were selected for using in the eggplant variety breeding program. The degree of the data given in Table 5 such as length of fruit, level of fruit colour at commercial harvesting, colour of flesh, level of brightness at fruit skin, and height of plant was mentioned in another research (Pirinç and Pakyurek, 2001). The mean of these values

Table 5. Rankit-Weighted Method*

\begin{tabular}{|c|c|c|c|}
\hline Characteristics & $\begin{array}{l}\text { Degree } \\
\text { of ratio }\end{array}$ & $\begin{array}{l}\text { Classification of } \\
\text { features }\end{array}$ & Degree of classes \\
\hline Length of fruit (cm) & 30 & $\begin{array}{l}33-25 \\
25-20 \\
20-18 \\
18-15\end{array}$ & $\begin{array}{l}10 \\
6 \\
4 \\
2\end{array}$ \\
\hline $\begin{array}{l}\text { Level of fruit colour at } \\
\text { commercial harvesting }\end{array}$ & 25 & $\begin{array}{l}\text { Dark purple } \\
\text { Dark purple-purple } \\
\text { Purple } \\
\text { purple-light purple } \\
\text { light purple }\end{array}$ & $\begin{array}{l}10 \\
8 \\
5 \\
2 \\
1\end{array}$ \\
\hline Colour of flesh & 5 & $\begin{array}{l}\text { Whitish } \\
\text { Greenish } \\
\text { Light green }\end{array}$ & $\begin{array}{l}10 \\
1 \\
3\end{array}$ \\
\hline Shape of apex & 10 & $\begin{array}{l}\text { Rounded } \\
\text { Pointed } \\
\text { Intended }\end{array}$ & $\begin{array}{l}10 \\
5 \\
3\end{array}$ \\
\hline $\begin{array}{l}\text { Level of brightness at } \\
\text { fruit skin }\end{array}$ & 20 & $\begin{array}{l}\text { Bright } \\
\text { Semi bright } \\
\text { Dull }\end{array}$ & $\begin{array}{l}10 \\
7 \\
3\end{array}$ \\
\hline Plant height $(\mathrm{cm})$ & 10 & $\begin{array}{l}200-150 \\
150-100 \\
100-50\end{array}$ & $\begin{array}{l}1 \\
10 \\
5\end{array}$ \\
\hline
\end{tabular}

*prepared by applying from Sürmeli and Şimşek (1991). 
Table 6. Calculated degree of lines after Rankit-Weighted Method

\begin{tabular}{|c|c|c|c|c|c|c|c|}
\hline Lines & $\begin{array}{l}\text { Length of } \\
\text { fruit }\end{array}$ & $\begin{array}{c}\text { Colour of fruit } \\
\text { at commercial } \\
\text { harvesting }\end{array}$ & $\begin{array}{l}\text { Colour } \\
\text { of flesh }\end{array}$ & $\begin{array}{l}\text { Shape } \\
\text { of apex }\end{array}$ & $\begin{array}{c}\text { Level of } \\
\text { brightness } \\
\text { at fruit skin }\end{array}$ & $\begin{array}{l}\text { Plant } \\
\text { height }\end{array}$ & $\begin{array}{l}\text { Total } \\
\text { degree }\end{array}$ \\
\hline Surtepe 1 & 180 & 250 & 50 & 200 & 200 & 70 & 950 \\
\hline Surtepe 2 & 180 & 250 & 50 & 200 & 200 & 70 & 950 \\
\hline Altinova 1 & 180 & 25 & 50 & 200 & 140 & 100 & 695 \\
\hline Altinova 2 & 60 & 25 & 5 & 200 & 200 & 100 & 590 \\
\hline Altinova 3 & 60 & 125 & 50 & 200 & 200 & 100 & 735 \\
\hline Altinova 4 & 120 & 125 & 5 & 30 & 200 & 100 & 580 \\
\hline Magarali 1 & 180 & 25 & 15 & 100 & 140 & 100 & 560 \\
\hline Magarali 2 & 120 & 200 & 50 & 100 & 140 & 100 & 710 \\
\hline Ugurlu 1 & 120 & 250 & 15 & 100 & 140 & 100 & 725 \\
\hline Mezra 1 & 60 & 250 & 5 & 100 & 140 & 100 & 655 \\
\hline Mezra 2 & 60 & 50 & 50 & 30 & 140 & 100 & 430 \\
\hline Mezra 3 & 60 & 25 & 15 & 30 & 140 & 100 & 370 \\
\hline Mezra 4 & 120 & 50 & 50 & 100 & 200 & 100 & 620 \\
\hline Mezra 5 & 120 & 250 & 50 & 100 & 140 & 100 & 760 \\
\hline Mezra 6 & 120 & 25 & 50 & 100 & 140 & 100 & 535 \\
\hline Keskince 1 & 120 & 200 & 50 & 100 & 140 & 100 & 710 \\
\hline Keskince 2 & 120 & 25 & 50 & 100 & 200 & 100 & 595 \\
\hline Keskince 3 & 120 & 250 & 50 & 100 & 140 & 100 & 760 \\
\hline Keskince 4 & 120 & 25 & 50 & 100 & 140 & 100 & 535 \\
\hline Keskince 5 & 60 & 125 & 50 & 100 & 140 & 100 & 575 \\
\hline
\end{tabular}

Selected lines are; Surtepe 1, Surtepe 2, Mezra 5 and Keskince 3. In addition, although Keskince 1 line received 710 points, it is acceptable within the above lines according to subjective observations. Surtepe I, Surtepe 2, Keskince 1 and Keskince 3 lines are recommended for kebabs which are consumed intensively by the people of Şanlıurfa, while Mezra 5 line is recommended for other kind of meals. Conservation and maintenance of these valuable genetic resources are necessary because these populations are important sources of diversity that can be used in future breeding programs (Balkaya and Karaagac 2005). The selected lines of Sanliurfa are canditates varieties for eggplant breeding programme. And these lines can be used for other researches sech as stress physology and other plant protection studies.

\section{Acknowledgements}

Ministry of Industry and Technology Southeastren Anatolia Project Regional Development Administration (GAP Administration).

\section{References}

Abak K., Sarı N., Daşgan H Y., (1996). Studies on production of seeds of some vegetables grown under the Harran Plain conditions. GAP-RDA and Cukurova University joint projects, C.U. Publications No:165, Adana. 
5, No.12, 2019

Açıkgöz, N., Akbaş, M.E., Moghaddam, A. ve Özcan, K., (1994=. PC'ler için Veritabanı Esaslı Türkçe İstatistik Paketi: TARIST, Tarla Bitkileri Kongresi, 25-29 Nisan 1994, Bornova-İzmir, 131-136s.

Anonymous, (1988). International Union for the Protection of New Varieties of Plants. Eggplant, Aubergine, Eierfrucht TG/117/3

Anonymous, TUIKK (2018). Turkish Statistical Institute Statistical Data Web: https://biruni.tuik.gov.tr/bolgeselistatistik

Balkaya A and Karaagac O (2005). Vegetable genetic resources of Turkey. Journal of Vegetable Science, 11(4): 81- 102.

Cakir Z, Balkaya A, Saribas S and Kandemir D (2017). The morphological diversity and fruit characterization of Turkish Eggplant (Solanum melongena L.) populations. Ekin Journal of Crop Breeding and Genetics, 3(2): 34-44.

Daunay MC, Lester RN, Gebhardt C, Hennart W, Jahn M and Doganlar S (2001). Genetic resources of eggplant (Solanum melongena L.) and allied species: a new challenge for molecular geneticists and eggplant breeders. Nijmegen University Press, Nijmegan, Netherlands pp. 251-274.

D'Anna F and Sabatino L (2013). Morphological and agronomical characterization of eggplant genetic resources from the Sicily area. Journal of Food, Agriculture \& Environment, 11(1): 401404.

Kumar SR, Arumugam T and Anandakumar CR (2013). Genetic diversity in eggplant. Plant Gene and Trait, 4(2): 4-8.

Küçük SA (2003). Solanaceae genetic resources activities in Turkey. National Collections. Solanaceae Genetic Resources in Europe. Report of two meetings 21 September 2001, Nijmegen, The Netherlands. 22 May 2003, Skierniwice, Poland.

Pirinç, V., (1999). An investigation on local eggplant populatioin of şanliuarfa with their selfing lines. Master Thesis. Science Institute of Harran University, Şanlıurfa, Turkey

Pirinç V. And A.Y. Pakyürek, (2001). An investigation on local eggplant populatioin of şanliuarfa with their selfing lines. In: Proc. XIth Eucarpia Meeting on Genetics and Breeding of Capsicum and Eggplant. pp: 233-7. April 9- 13, Antalya, Turkey.

Pirinç, V and Pakyürek A.Y (2004). A study on comparison of eggplant population with their selfing lines. International Journal of Agriculture and Biology, 6(5): 874-876.

Sarıbas, Ş., Çakır, Z, Balkaya, A. and Kandemır, D. ( 2019). Determination of Superior Turkish Eggplant (Solanum melongena L.) Genotypes by Pedigree Selection Method. Dergipark. Ekin Journal of Crop Breeding and Genetics Arşiv Cilt 5, Sayı 1

Sürmeli, N. and G. Şimşek, (1991). Çorbaci pepper breeding. Hort. J., 20:1- 6

Şalk, A., Arın, L, Deveci, M., Polat, S., 2008. Özel Sebzecilik. s.331.Tekirdağ.

Tümbilen Y (2007). Determination of genetic diversity between eggplant and its wild relatives. Master Thesis. The Graduate School of Engineering and Sciences of İzmir Institute of Technology, Molecular Biology and Genetics, 76 p.

Tümbilen Y, Frary A, Mutlu S, Doğanlar S. 2011. "Genetic diversity in Turkish eggplant (Solanum melongena) varieties as determined by morphological and molecular analyses" International Research Journal of Biotechnology (ISSN: 2141-5153) Vol. 2(1) pp.016-025, January. 